\title{
Effect of Thickness and Composition Ratio of Poly(3-Hexylthiophene) and [6,6]-Phenyl C60-Butyric Acid Methyl Ester Thin Film on Optical Absorption for Organic Solar Cell Fabrication
}

\author{
Sunday Wilson Balogun ${ }^{1,}$, Yekini Kolawole Sanusi ${ }^{1,2}$ \\ ${ }^{1}$ Department of Materials Science and Engineering Laboratory, Kwara State University Malete, Ilorin, Nigeria \\ ${ }^{2}$ Department of Pure and Applied Physics, Ladoke Akintola University of Technology, Ogbomoso, Nigeria \\ Email address: \\ sbalogun94@gmail.com (S. W. Balogun), sanusiyk33@gmail.com (Y. K. Sanusi) \\ ${ }^{*}$ Corresponding author
}

To cite this article:

Sunday Wilson Balogun, Yekini Kolawole Sanusi. Effect of Thickness and Composition Ratio of Poly(3-Hexylthiophene) and [6,6]-Phenyl C60-Butyric Acid Methyl Ester Thin Film on Optical Absorption for Organic Solar Cell Fabrication. Journal of Photonic Materials and Technology. Vol. 5, No. 1, 2019, pp. 5-10. doi: 10.11648/j.jmpt.20190501.12

Received: February 21, 2019; Accepted: April 4, 2019; Published: May 6, 2019

\begin{abstract}
A Blend of poly(3-hexylthiophene) (P3HT) and [6,6]-phenyl C60-butyric acid methyl ester (PCBM), a fullerene derivate based donor-acceptor copolymer, is one of the widely used organic solar cell materials for photon-electron conversion. Thin films were developed, characterized, and optimized for optical absorbance. Absorption spectra were measured using a UV-VIS spectrophotometer. In this work, the effects of composition ratios of $\mathrm{P} 3 \mathrm{HT}: \mathrm{PC}_{60} \mathrm{BM}$ and various thicknesses was studied in ambient conditions. The P3HT:PC ${ }_{61} \mathrm{BM}$ thin film was deposited in two different composition ratio $(1: 1$ and $1: 3)$ and fabricated at seven different thicknesses of $20 \mathrm{~nm}, 30 \mathrm{~nm}, 35 \mathrm{~nm}, 87 \mathrm{~nm}, 98 \mathrm{~nm}, 115 \mathrm{~nm}$, and $146 \mathrm{~nm}$ corresponding to spin coating speeds of $4000 \mathrm{rpm}, 3000 \mathrm{rpm}, 2000 \mathrm{rpm}, 1500 \mathrm{rpm}, 1250 \mathrm{rpm}, 1000 \mathrm{rpm}$, and $750 \mathrm{rpm}$, respectively. $\mathrm{P} 3 \mathrm{HT}: \mathrm{PC}_{60} \mathrm{BM}$ thin film composition ratio of $1: 1$ with thickness of $87 \mathrm{~nm}$ shows relatively better photon absorption optical parameter than $\mathrm{P} 3 \mathrm{HT}: \mathrm{PC}_{60} \mathrm{BM}$ composition ratio of 1:3. P3HT: $\mathrm{PC}_{61} \mathrm{BM}$ solution coated at a spin speed of $1500 \mathrm{rpm}$ shows a better absorption of photon energy. The results showed that the optimum thickness of the thin film is $87 \mathrm{~nm}$ at composition ratio of 1:1. Energy band gap values of composition ratio of 1:3 is observed to decreases with increase in spin- speed from $3.9 \mathrm{eV}$ to $3.7 \mathrm{eV}$. The results can be used as a guideline for improving the design and fabrication of active layer of organic solar cells.
\end{abstract}

Keywords: Optical Transmittance, Reflectance, Absorbance, Organic Thin Film, P3HT, PCBM Blend, Bandgap Energy

\section{Introduction}

The demand for clean energy sources has increased, leading to a rapid growth in the field of research and development of solar energy. Solar cells are devices which convert the light into electrical energy [1]. Solar cells can be fabricated using organic, inorganic or hybrid materials and are divided into three different generations [2]. The First generation consists of crystalline semiconductor wafers with a thickness of 200-300 $\mu \mathrm{m}$. The Second-generation solar cells are based on thin film technology having thickness, usually in the range of 1-2 $\mu \mathrm{m}$. Third generation solar cells are under research process, to increase the efficiency. Third generation solar cells, instead of expensive semiconductors, usually employ solution-processed materials such as polymers, nanoparticles and additives which make them easier to manufacture using cheap methods and processes [3]. In the field of polymer-based photovoltaic cells, blend of poly(3hexylthiophene) (P3HT), a polymer, and [6,6]-phenyl C61butyric acid methyl ester (PCBM), a fullerene derivate based donor-acceptor copolymer, is one of the most-studied active materials organic solar cell materials for photon-electron conversion [4-15] Organic polymers such as P3HT:PCBM blends have wider band gaps than natural semiconductors [16-17]. This paper studied the effects of composition ratios of $\mathrm{P} 3 \mathrm{HT}: \mathrm{PC}_{61} \mathrm{BM}$ on photo-absorption optical properties 
under various thicknesses in ambient conditions for photoactive layer device. Very limited research efforts have so far been dedicated to this topic. Most research effort has been focused on the efficiency improvement and analyses of film morphological behavior.

\section{Materials and Methods}

To study the effect of varying the thickness and composition ratio of Poly(3-hexylthiophene) (P3HT) and [6,6]-phenyl C60-butyric acid methyl ester (PCBM) thin film on optical absorption: A precursors for active layer organic solar cell fabrication. Thin film of P3HT:PCBM was deposited on cleaned glass substrate using the materials itemized below.

\subsection{Materials}

[6,6]-phenyl $\mathrm{C}_{61}$ butyric acid methyl ester (PCBM), with $>99.5 \%$ purity, product of Nederlands was obtained from Sigma - Aldrich. Poly (3-hexylthiopene-2,5-diyl) regioregular (P3HT) product of USA, was supplied by Sigma - Aldrich. a)

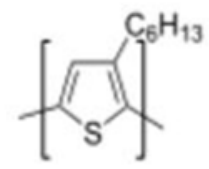

b)

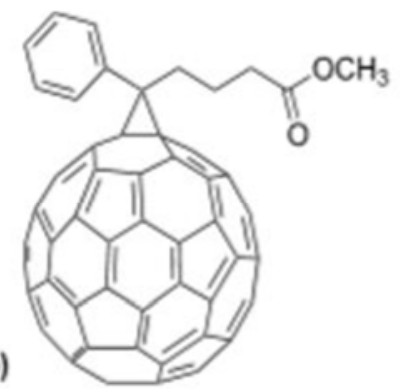

Figure 1. Structure of (a) P3HT and (b) PCBM Beilstein J. Nanotechnol. (2018, 9, 1108-1115).

\subsection{Methods: The Following Experimental Procedures Were Carried Out}

\subsubsection{Substrate Preparation}

Clean rectangular glass slides of dimension $25.4 \mathrm{~mm}$ by $76.2 \mathrm{~mm}$ were used as substrates. The glass substrates were washed with detergent solution for 10 to 15 minutes in ultrasonic sonicator and rinsed in distilled water for 15 minutes at $30{ }^{\circ} \mathrm{C}$. The substrate was cleaned with Isopropanol alcohol [IPA] in ultrasonic bath for 15 minutes at $30{ }^{\circ} \mathrm{C}$ and dried in a stream of nitrogen gas $\left(\mathrm{N}_{2}\right)$.

\subsubsection{Preparation of P3HT, PCBM and P3HT:PCBM Blend Solutions}

$1 \mathrm{ml}$ of chloroform solvent was added into $15 \mathrm{mg}$ of poly (3-hexylthiophene) (P3HT) and to $15 \mathrm{mg}$ of $[6,6]$ phenyl Cbutyric acid methyl ester (PCBM) all from Sigma Aldrich to form $\mathrm{P} 3 \mathrm{HT}$ and $\mathrm{PC}_{60} \mathrm{BM}$ solutions separately. The two solutions then underwent ageing process by using magnetic stirrer for 3 hours without heat to allow the organic materials mixture to fully dilute into the solvent. Composite solutions were prepared by mixing $\mathrm{P} 3 \mathrm{HT}$ solution with $\mathrm{PC}_{60} \mathrm{BM}$ solution in composition ratios of $1: 1$ and $1: 3$ respectively. The solutions were stirred for another 3 hours using magnetic stirrer for homogeneous mixture. The solutions were thoroughly completely covered from light ray using an aluminum foil to avoid degradation of the materials.

\subsubsection{P3HT:PC 60 BM Thin Film Fabrication}

Spin- coater Model WS-650MZ-23NPP was used for deposition of solution on substrate. P3HT:PCBM solution of composition ratios of $(1: 1,1: 3)$ were spin-coated onto cleaned glass substrate respectively at spin speed of 4000 revolutions per minute (rpm), 3000rpm, 2000rpm, 1500rpm, 1250rpm, 1000rpm, and 750rpm, respectively for all films. P3HT:PC ${ }_{61} \mathrm{BM}$ thin film was deposited in two different composition ratio (1:1 and $1: 3)$ and fabricated at seven different thicknesses of $20 \mathrm{~nm}, 30 \mathrm{~nm}, 35 \mathrm{~nm}, 87 \mathrm{~nm}, 98 \mathrm{~nm}$, $115 \mathrm{~nm}$, and $146 \mathrm{~nm}$ corresponding to spin coating speeds of $4000 \mathrm{rpm}, 3000 \mathrm{rpm}, 2000 \mathrm{rpm}, 1500 \mathrm{rpm}, 1250 \mathrm{rpm}, 1000$ $\mathrm{rpm}$, and $750 \mathrm{rpm}$, respectively.

\subsubsection{P3HT:PCBM Thin Film Optical Properties Characterization}

Transmittance and Reflectance of P3HT:PCBM thin film was measured by an optical spectrophotometer (UV-VIS Avantes, Avalight-DH-5BAL). Absorption spectra was calculated using equation (1).

$$
\text { Absorbance }=2-\log 10(\% / 0 \mathrm{~T})
$$

Where $\%{ }_{0} \mathrm{~T}$ is percentage transmittance

Results from the UV-VIS spectra helped to map the optical absorption and transmittance characteristics of the materials which included the percentage absorption and the wavelength position. Refractive index of P3HT:PCBM thin film was calculated using equation (2) [18].

$$
\text { Refractive index }(\mathrm{n})=\left[1+(\mathrm{R})^{0.5} / 1-(\mathrm{R})^{0.5}\right]
$$

Reflectance $\mathrm{R}$ values was obtained from UV-VIS spectrophotometer measurement. The variation of refractive index with wavelength is shown in figure 8 and 9.

According to Tauc (1970) [19] the dependence of the absorption coefficient $\alpha$ on the photon energy h $v$ for nearedge optical absorption in semiconductors takes the form equation (3).

$$
(\alpha h v)^{1 / m}=\mathrm{k}\left(\mathrm{hv}-\mathrm{E}_{\mathrm{g}}\right)
$$

where $E_{g}$ is the optical band gap, $\mathrm{k}$ is a constant and $\mathrm{m}=1 / 2$ for an allowed direct energy gap and $m=3 / 2$ for a forbidden direct energy gap. In order to determine the optical band gap of a semiconductor thin film, taking $\mathrm{m}=1 / 2,(\alpha \mathrm{h} v)^{2}$ must be plotted versus $h v$ using the data obtained from the optical absorption spectra. The direct bandgap of the semiconductor thin film is obtained by extrapolating the linear part to the zero of the ordinate. The absorption coefficient of thin film is calculated from equation (4) [20].

$$
\alpha=2.303(\mathrm{~A} / \mathrm{t})
$$


Where, $\mathrm{A}$ is absorbance and $\mathrm{t}$ is the thickness

$$
\text { Band Gap Energy }(E)=h c / \lambda
$$

Where $\mathrm{h}=$ planks constant $=6.626 \times 10^{-34}$ joules sec. $\mathrm{C}=$ speed of light $=3.0 \times 10^{8} \mathrm{~meter} / \mathrm{sec}$. where $1 \mathrm{ev}=1.6 \times 10^{-19}$ joules (conversion factor). For calculation of the optical band gap of films, the curve of $(\alpha h v)^{2}$ vs. ho was plotted. The energy band gap was obtained from straight line plot of ( $\alpha$ hv) ${ }^{2}$ versus ho by extrapolating of the line to base line in Figure 10 and figure 11.

\section{Results and Discussion}

Results from the UV-VIS spectra helped to map the optical transmittance, reflectance, and absorption characteristics of the materials which included the percentage absorption and the wavelength position.

\subsection{Optical Transmittance}

Figure 2 shows the graph of transmittance versus wavelength of composition ratio 1:1 at different spin speeds. Deposition at $3000 \mathrm{rpm}$ has two peaks one at $350 \mathrm{~nm}$ corresponding to $48 \%$ and at $600 \mathrm{~nm}$ corresponding to $92 \%$. Figure 3 depicts composition ratio 1:3 which has its peaks at $350 \mathrm{~nm}, 40 \%$ and $500 \mathrm{~nm}$ with spin speed at $3000 \mathrm{rpm}$.

\subsection{Optical Reflectance}

Figure 4 shows the graph of reflectance against wavelength of composition ratio $1: 1$ spin coating done at $1000 \mathrm{rpm}$ has the highest reflectance followed by the one done at $750 \mathrm{rpm}$. Figure 5 of reflectance versus wavelength graph at composition ratio 1:3 shows that deposition done at $4000 \mathrm{rpm}$ has the highest reflectance.

\subsection{Optical Absorbance}

Figure 6 shows the optical absorption spectra of $\mathrm{P} 3 \mathrm{HT}: \mathrm{PC}_{60} \mathrm{BM}$ thin films with composition ratio $1: 1$ and fabricated in seven different thicknesses, the one fabricated at $87 \mathrm{~nm}$ produce the highest optical absorption in the wavelength range 400 to $600 \mathrm{~nm}$ with peak at 500nm. Figure 7 shows the optical absorption properties of $\mathrm{P} 3 \mathrm{HT}: \mathrm{PC}_{60} \mathrm{BM}$ thin films in composition ratio of $1: 3$, the highest absorption occurs in the wavelength range 400 to $510 \mathrm{~nm}$ having peak at $470 \mathrm{~nm}$ in the visible wavelength band with $87 \mathrm{~nm}(1500 \mathrm{rpm})$ thickness.

\subsection{Refractive Index}

Refractive index of P3HT:PCBM thin film was calculated. The variation of refractive index with wavelength is shown in figure 8 and 9. Deposition done at spin speed $4000 \mathrm{rpm}$ in figure 9 has the highest refractive index.

\subsection{Optical Band Gap Energy}

The energy band gap was obtained from straight line plot of (ahv) ${ }^{2}$ versus ho by extrapolating of the line to base line in Figure 10 and figure 11, the curve of $(\alpha h v)^{2}$ vs. ho. The Optical energy band gap values were evaluated by plot of $(\alpha h v)^{2}$ versus ho. Band gap value of composition ratio $1: 1$ at spin speed $3000 \mathrm{rpm}(30 \mathrm{~nm})$ is $3.85 \mathrm{eV}$ in figure 10 . While the band gap values of composition ratio of $1: 3$ is observed to decreases with increase in spin- speed from $3.9 \mathrm{eV}$ to $3.7 \mathrm{eV}$ in figure 11 .

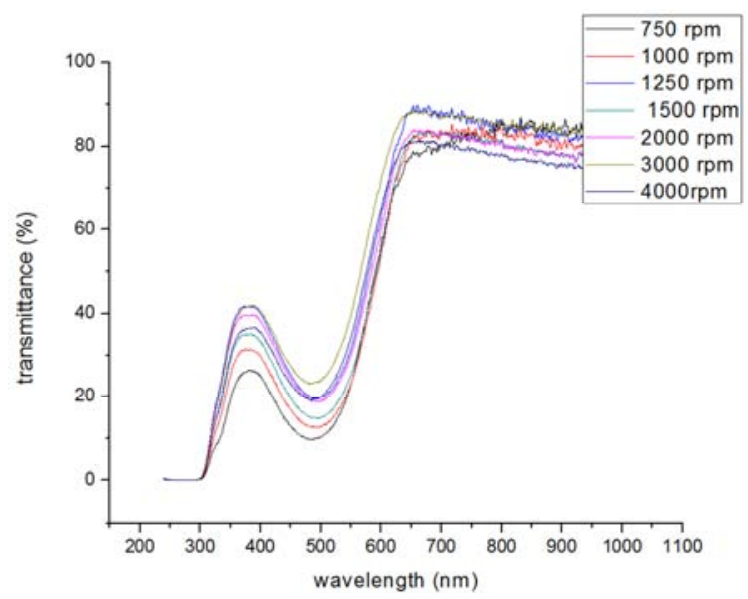

Figure 2. Transmittance spectrum of P3HT:PC ${ }_{60} B M(1: 1)$ thin films at different thicknesses of deposition.

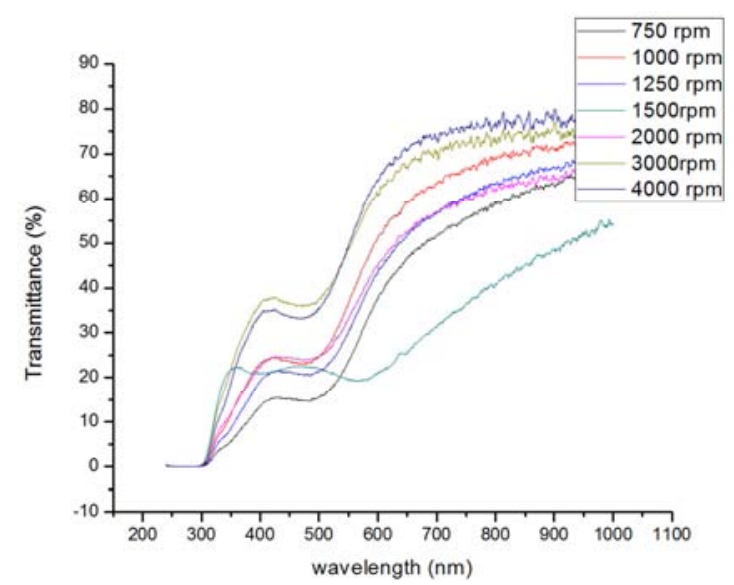

Figure 3. Transmittance spectrum of $P 3 H T: P C_{60} B M(1: 3)$ thin films at different thicknesses of deposition.

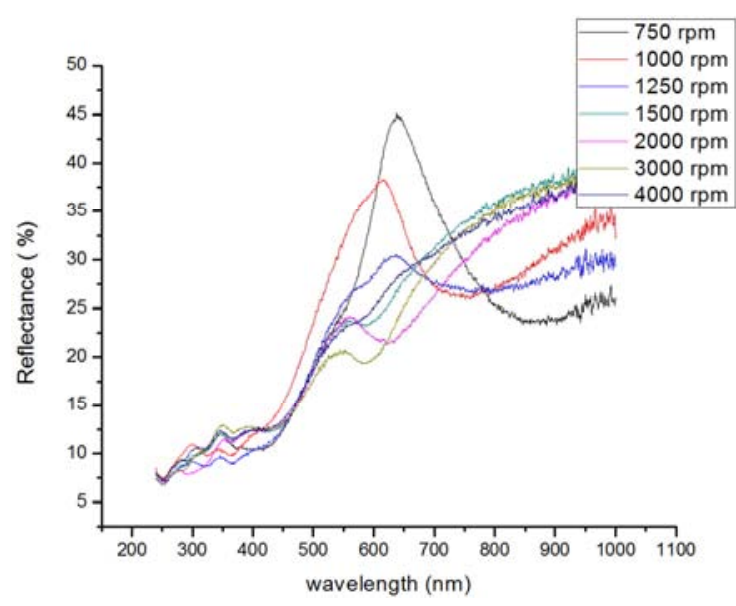

Figure 4. Reflectance spectrum of $P 3 H T: P C_{60} B M(1: 1)$ thin films at different thicknesses of deposition. 
8 Sunday Wilson Balogun and Yekini Kolawole Sanusi: Effect of Thickness and Composition Ratio of Poly(3-Hexylthiophene) and [6,6]-Phenyl C60-Butyric Acid Methyl Ester Thin Film on Optical Absorption for Organic Solar Cell Fabrication

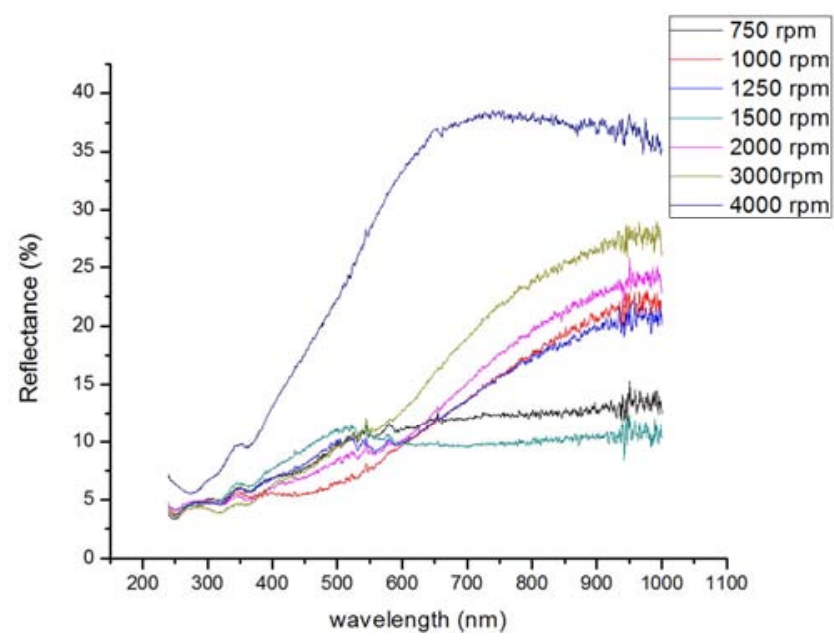

Figure 5. Reflectance spectrum of $P 3 H T: P C_{60} B M(1: 3)$ thin films at different thicknesses of deposition.

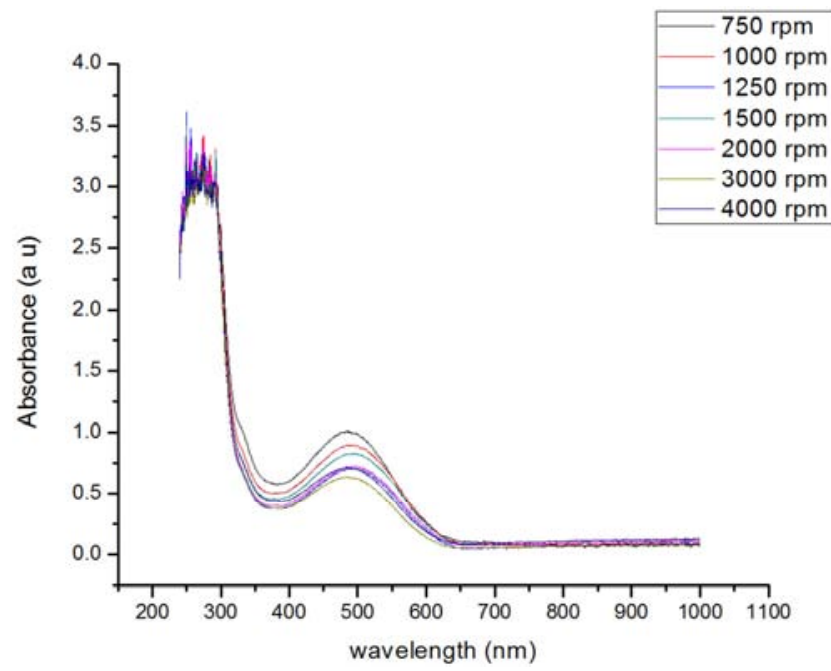

Figure 6. Absorption spectrum of P3HT:PC ${ }_{60} B M(1: 1)$ thin films at different thicknesses of deposition.

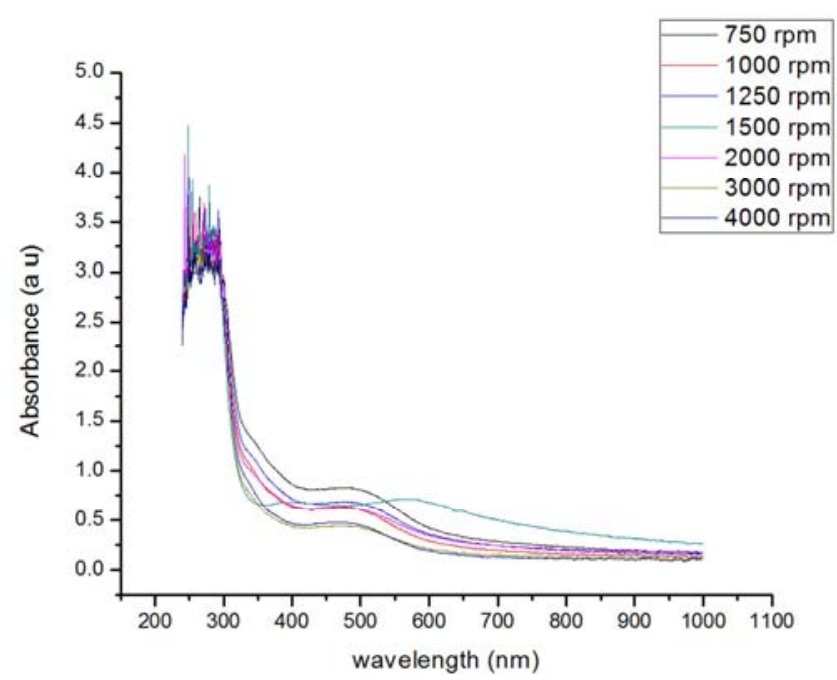

Figure 7. Absorption spectrum of P3HT:PC ${ }_{60} B M(1: 3)$ thin films at different thicknesses of deposition.

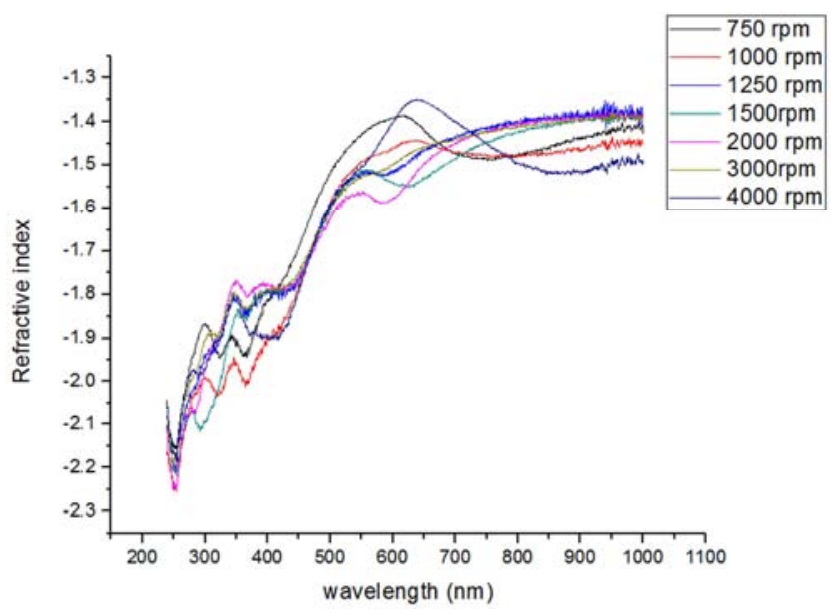

Figure 8. Refractive index versus wavelength graph of P3HT:PC60BM (1:1) thin films at different thicknesses of deposition.

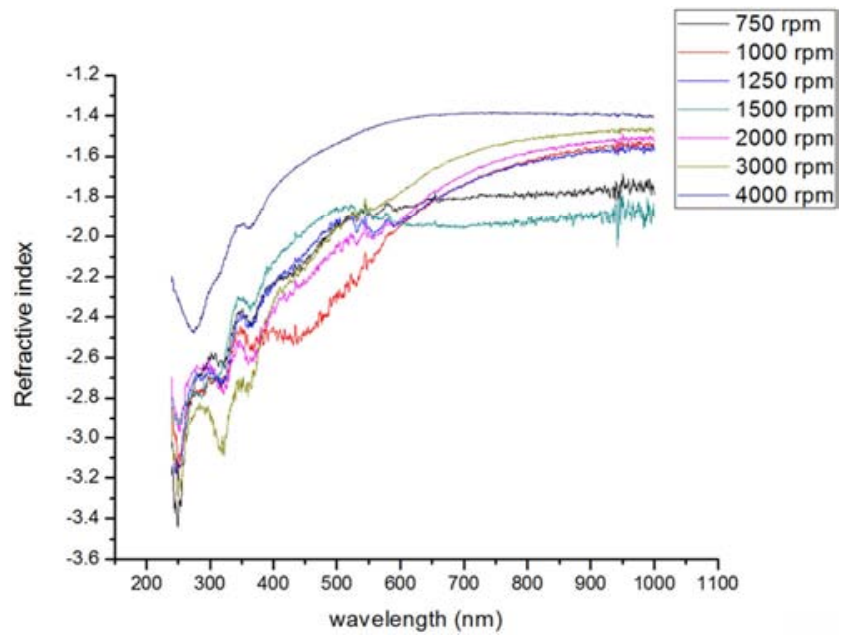

Figure 9. Refractive index versus wavelength graph of $P 3 H T: P C_{60} B M(1: 3)$ thin films at different thicknesses of deposition.

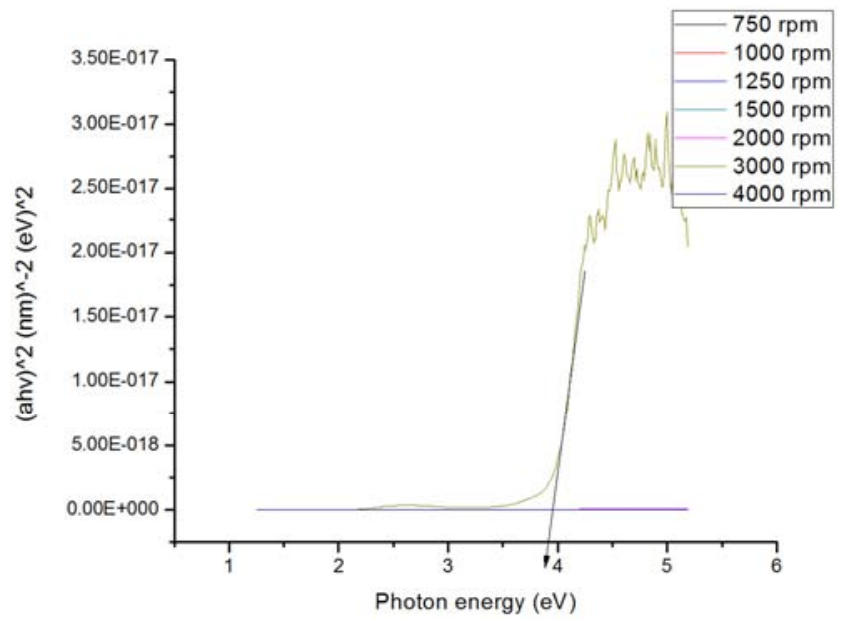

Figure 10. Plot of $(\alpha h v)^{2}$ versus hv for $P 3 H T: P C_{60} B M(1: 1)$ thin films at different thicknesses of deposition. 


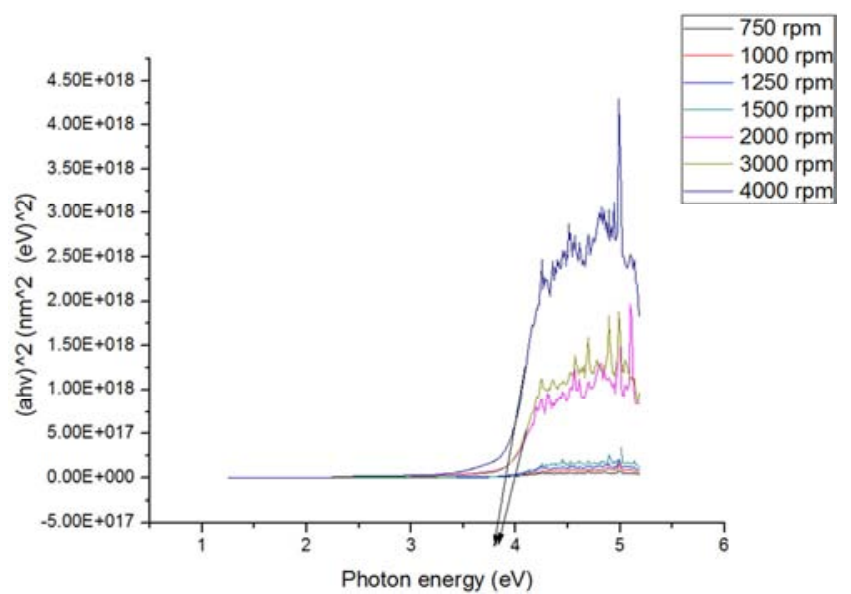

Figure 11. Plot of $(\alpha h v)^{2}$ versus $h v$ for $P 3 H T: P C_{60} B M$ (1:3) thin films at different thicknesses of deposition.

\section{Conclusion}

This work presented an in-depth study of the effect of Varying the Thickness and composition ratio of Poly(3hexylthiophene) (P3HT) and [6,6]-phenyl C60-butyric acid methyl ester (PCBM) Thin Film on optical absorption spectroscopy. We have investigated thin films of P3HT:PCBM blends deposited by spin-coating. Thin film of P3HT:PCBM as the photoactive layer have been optimized. The highest measured optical absorption is $1.0 \mathrm{a}$ $\mathrm{u}$ at thin film thickness of $87 \mathrm{~nm}(1500 \mathrm{rpm})$ corresponding to $500 \mathrm{~nm}$ in the visible wavelength band. P3HT:PCBM blend ratio of 1:1 produce the highest optical absorption than composition ratio of $1: 3$. Thin film deposited at 1500 rpm corresponding to thickness of $87 \mathrm{~nm}$ produce the best photo absorption. The refractive indices were calculated, for composition ratio 1:3 deposited at $4000 \mathrm{rpm}$ exhibited highest refractive index in the visible range of wavelength spectrum. The Optical energy band gap values were evaluated by plot of $(\alpha h v)^{2}$ versus ho. Band gap value of composition ratio $1: 1$ at spin speed $3000 \mathrm{rpm}(30 \mathrm{~nm})$ is $3.85 \mathrm{eV}$. While the band gap values of composition ratio of $1: 3$ is observed to decreases with increase in spin- speed from $3.9 \mathrm{eV}$ to $3.7 \mathrm{eV}$. As the thickness decreases the band gap energy decreases. The results can be used as a guideline for improving the design and fabrication of active layer of organic solar cells.

\section{Conflict of Interests}

The authors declare that there is no conflict of interests regarding the publication of this article.

\section{Acknowledgements}

The experimental work was carried out at Kwara State University Malete - Ilorin in Materials Science and Engineering Laboratory.

\section{References}

[1] Atwater H. A., Polman A (2010). Plasmonics for improved photovoltaic devices. Nat Mater 9: 205-213.

[2] Heeger A. J. (2014). Bulk hetero junction solar cells: understanding the mechanism of operation. Adv Mater 26: 1028.

[3] Krebs, F. C. (2009) Fabrication and processing of polymer solar cells: A review of printing and coating techniques. Sol. Energy Mater. Sol. Cells, 93, 394-412.

[4] Dyfrig M., Anthony M. H., David J. (2017).: Mixing in PCBM/P3HT bilayers, using in situ and ex situ neutron reflectivity. J. Mater. Res., Vol. 32, No. 10,

[5] Francesca M. ], Borsacchi S., Spera S., Carbonera C., Cominetti A., Geppi M. (2013) P3HT/PCBM Photoactive Materials for Solar Cells: Morphology and Dynamics by Means of Solid-State NMR J. Phys. Chem. C, 117 (1), pp 131-139 DOI: 10.1021/jp3103904.

[6] Von H. E., Dyakonov, V., Parisi, R. (2005). Study of field effect mobility in PCBM films and P3HT:PCBM blends. Sol. Energy Mater. Sol. Cell, 87(1-4), 149-156. DOI: 10.1016/j.solmat.2004.06.014.

[7] Lu Y. M., Chiang C.-H., Lien-Chung Hsu S. (2014). The performance of polymer solar cells based on P3HT:PCBM after post-annealing and adding titanium dioxide nanoparticles Materials Research Innovations 18:sup3.53102-53-105.

[8] Shang-ChouChang, Yu-JenHsiao, To-SingLi (2013). P3HT:PCBM Incorporated with Silicon Nanoparticles as Photoactive Layer in Efficient Organic Photovoltaic Devices Hindawi Publishing Corporation J Nanomaterials Volume 2013,ArticleID354035,4pages //dx.doi.org/10.1155/2013/3.

[9] Berger P. R., Kim M. (2018); Polymer solar cells: P3HT:PCBM and beyond J. Renewable and Sustainable Energy 10, 013508 https: //doi.org/10.1063/1.5012992.

[10] Malti L. Chiali A., Sari N. C. (2016). Numerical study of electrical behavior of P3HT/PCBM bulk heterojunction solar cell X, Appl. Sol. Energy, 2016, Vol. 52, No. 2, pp. 122-127. (C) Allerton Press, Inc., 2016. April 2016, Volume 52, Issue 2, pp 122-127|.

[11] Chaudhary N., Chaudhary R., Kesari J. P., Patra A.(2017). Effect of composition ratio of $\mathrm{P} 3 \mathrm{HT}: \mathrm{PC}_{61} \mathrm{BM}$ in organic solar cells: optical and morphological properties Materials Research Innovations_Vol 22, No 5 Pages 282-286 https: //doi.org/10.1080/14328917.2017.1317061.

[12] Lee J. U., Do Kim Y., Jo J. W., Kim J. P., Won Ho Jo ( 2011). Efficiency enhancement of P3HT/PCBM bulk heterojunction solar cells by attaching zinc phthalocyanine to the chain-end of P3HT J. Mater. Chem., 21, 17209-17218 DOI: 10.1039/C1JM11563D.

[13] Hajduk B., Bednarski H., Jarząbek B., Janeczek H., Nitschke SS P. (2018). P3HT:PCBM blend films phase diagram on the base of variable-temperature spectroscopic ellipsometry Beilstein J. Nanotechnol. 2018, 9, 1108-1115, doi: 10.3762/bjnano.9.102. 
10 Sunday Wilson Balogun and Yekini Kolawole Sanusi: Effect of Thickness and Composition Ratio of Poly(3-Hexylthiophene) and [6,6]-Phenyl C60-Butyric Acid Methyl Ester Thin Film on Optical Absorption for Organic Solar Cell Fabrication

[14] Lusi S , Risdiana, A. B , Annisa A, Rustam E.S , Rahmat H , Tobat P. I. Saragi, I. Kawasaki, Isao W (2015) "Study of Charge Carrier Dynamics of P3HT:PCBM Blend for Active Material Solar Cell Using Muon Spin Relaxation", Materials Science Forum, Vol. 827, pp. 168-173.

[15] Yasser A. M. I, Soga T., Jimbo T. (2012). Investigation of PCBM Concentration on the Performance of Small Organic Solar Cell: ISRN Renewable Energy International Scholarly Research Network ISRN Renewable Energy Volume 2012, Article ID 385415, 8 pages doi: 10.5402/2012/385415.

[16] Krebs F. C. Polymeric Solar Cells (2010); DEStech Publications, Inc.: Lancaster, PA, USA, 7.

[17] Dang, M. T., Hirsch, L. and Wantz, G. (2011). P3HT:PCBM,
Best Seller in Polymer Photovoltaic Research. $A d v$. Mater.,23,3597-3602. dx.doi. org/10.1002/adma.201100792.

[18] Hussein, H.F., Shabeeb, G. M., Sh. Hashim. S. (2011). Preparation ZnO Thin Film by using Sol-gel-processed and determination of thickness and study optical properties. $J$. Mater. Environ. Sci. 2 (4) 423-426. http: //www.jmaterenvironsci.com.

[19] Tauc J., (1970). The Optical properties of solids (NorthHolland, Amsterdam).

[20] Kumar, K. Balachandr, P. Raji (2011). Synthesis and Characterization of Nano Zinc Oxide by sol gel Spin Coating. Recent Research in Science and Technology, 3 (3): 48-52. www.recent-science.com. 